\title{
Extrapelvic endometriosis
}

INSERM

\section{Source}

INSERM. (1999). Orphanet: an online rare disease and orphan drug data base. Extrape/vic endometriosis. ORPHA:137820

Rare endometriosis is a rare, non-malformative gynecologic disease characterized by the presence of functional endometrial glands and stroma in extrapelvic locations, such as lungs, pleura, kidneys, bladder, abdominal wall, umbilicus, and cesarean section scar among others. Clinical manifestations are menstrually-related and depend on the location of the ectopic tissue, but in general include pain, mass/nodule, swelling and/or bleeding in the involved area. 